\title{
NÁVRH NA ZVÝŠENIE ATRAKTIVITY ORAVSKÉHO REGIÓNU CESTOVNÉHO RUCHU PROSTREDNÍCTVOM ELEKTRONICKÝCH TECHNOLÓGIÍ
}

\author{
Zuzana Rampašeková, Ján Lacika, Štefan Kováčik
}

\begin{abstract}
Based on analysis of the natural environment, market survey in terms of available tourism products and knowledge of customer needs by an electronic questionnaire method, we created a proposal of an absent type of demand of the Orava Tourism Region. We created a new product focused on the presentation of the existing extreme sports in the region called "Orava As You May Not Know It." For its promotion, we chose rather more effective than costly form by using electronic technologies that help stimulate demand and bring long-term prosperity of the territory.
\end{abstract}

Keywords: marketing of companies, type of demand, type of marketing, tourism product

\section{Úvod}

Jednou z neopakovatel'ných destinácií cestovného ruchu (d’alej CR) Slovenska, ktorá láka turistov, je Oravský región cestovného ruchu. Na Slovensku ide o menej propagovaný región ako všeobecne známy Tatranský alebo Liptovský región cestovného ruchu. Spomínaný región je charakteristický svojou prírodou, ktorú by sme vd’aka nami navrhovaným absentujúcim materiálom v internetovom prostredí, chceli spropagovat'. Ide o materiál, ktorý si môže vytvorit' každé ubytovacie zariadenie $\mathrm{z}$ hl'adiska dlhodobej prosperity. Mnohé ubytovacie zariadenia sa totiž sústred'ujú len na služby v podobe ubytovania, stravovania, wellnes služieb, ale zabúdajú na vytvorenie návrhu programu pre svojich hostí. Domnievame sa, že vytvorenie vlastného originálneho propagačného materiálu pre rozvoj CR v príslušnom prostredí, je úloha každého existujúceho zariadenia. Stanovením si či už všeobecných alebo konkrétnych ciel'ov v marketingovom manažmente podnikov $\mathrm{CR}$, môže príst' $\mathrm{k}$ zvýšeniu podielu na trhu, $\mathrm{k}$ zvýšeniu zisku a k rozšíreniu klientely. Preto sme sa pokúsili v uvedenom príspevku navrhnút' pre marketing podnikov nový propagačný materiál poskytujúci prehl'ad aktivít, ktoré ponúkajú návštevníkom neopakovatel'né zážitky. Zároveň navrhujeme metodiku tvorby takýchto propagačných materiálov pre l'ubovol'ný región. 


\section{Teoretické východiská}

Legislatíva Slovenskej republiky definuje produkt CR ako „súbor služieb, ktoré produkuje a ponúka ciel’ové miesto, podniky a inštitúcie, ktoré majú schopnost' uspokojit' potreby návštevníkov a vytvorit' tak komplexný súbor zážitkov“ (zákon č. 91/2010 Z. z.).

Podobne vymedzuje tento pojem aj Gučík (2000), hovorí o ňom ako o „Všetkom čo sa ponúka na trhu cestovného ruchu, má schopnost' uspokojit' potreby návštevníkov a vytvorit' tak komplexný súbor zážitkov. Je to súbor služieb, ktoré produkuje a ponúka ciel'ové miesto (primárna ponuka), podniky a inštitúcie cestovného ruchu (sekundárna ponuka)“.

Gučík a kol. (2006) podávajú aj pohl’ad na produkt cestovného ruchu z hladiska návštevníka: ,je to vždy súbor (balík) služieb, pre ktorý je charakteristická vzájomná podmienenost' a komplementarita. Zákazník si produkt skladá zvyčajne sám, kombináciou rôznych služieb. S ohl'adom na nemateriálny charakter nie je možné služby vopred vyskúšat', preto pri ich ponuke majú dôležitú úlohu informácie." Túto definíciu by sme mohli chápat' aj ako užšie vymedzenie produktu cestovného ruchu.

Kuhn, Tomášová (2011) tvrdia že produkt turizmu nie je jednoduché definovat'. Za najširšiu definíciu produktu cestovného ruchu považujú: „zážitok návštevníka v ciel'ovom mieste - destinácii“, kde podl'a nich patrí všetko od získavania informácií a rezervácie pred cestou, cez cestovanie na miesto pobytu, až po usmievavost' personálu v ciel'ovom mieste. Pod užším vymedzením produktu cestovného ruchu uvedení autori myslia "napr. pobytový balík, v ktorom sú na určitý čas (napr. na 3 dni) skombinované vybrané služby (napr. ubytovanie, lyžovanie a wellness).“

Musíme konštatovat', že všetky predchádzajúce definície sú si vel’mi podobné a neobsahujú žiadne protichodné tvrdenia. Zhodne tvrdia, že produkt cestovného ruchu môže byt' všetko, čo je spojené s tým, s čím príde návštevník do kontaktu počas realizácie turistickej aktivity. Do toho spadá už získavanie informácií, cestovanie, ubytovane atd'.

\section{Ciel', materiál a metodika skúmania}

Ciel'om príspevku je vytvorenie vol’ne dostupného elektronického propagačného materiálu, ktorý by návštevníkom Oravy ponúkol možnosti na aktívny oddych s využitím prírodného potenciálu Oravského regiónu cestovného ruchu. Pokúsili sme sa vytvorit' aj metodiku pre tvorbu propagačných materiálov CR pre jednotlivé destinácie ako aj samotné podniky a zariadenia, prípadne TIK a cestovné kancelárie $\mathrm{z}$ dôvodu originality vytváraných produktov. Nakol'ko z vlastných skúseností vieme, že jednotlivé podniky v regióne sa zameriavajú skôr na služby stravovacie, ubytovacie a iné, absentuje služba tvorby produktov, ktoré 
by zvyšovali imidž regiónu a zároveň umožnili návštevníkom aktívny oddych v uvedenej destinácii. Aj autori Šolcová, Kasagranda, Krogmann (2018) navrhujú produkt pre aktívny oddych. Domnievame sa, že takýto druh produktu je v marketingu podnikov rovnako dôležitý ako ostatné poskytované služby. Výskum pre tvorbu produktu prebiehal $\mathrm{v}$ troch fázach:

1. V analytickej fáze výskumu sme sa zamerali na prieskum trhu vlastným terénnym mapovaním. Zist'ovali sme aké produkty CR na trhu existujú, resp. kto zabezpečuje ich tvorbu.

2. V druhej fáze výskumu sme sa zamerali na plánovanie. Bolo treba zistit' dopyt trhu a preto sme zrealizovali elektronickou formou dotazníkový prieskum. Oslovili sme 112 reálnych ako aj potenciálnych návštevníkov Oravského regiónu CR, ktorých bolo spolu 112. Dotazník sme vytvorili cez bezplatnú službu, ktorú ponúka aplikácia GoogleDocs. Následne sme pomocou emailového dotazníka oslovili respondentov a webový dotazník sme umiestnili na dve diskusné fóra (www.reespace.sk.; www.diskusneforum.sk), kde sa do dotazníka mohli zapojit' registrovaní ako aj neregistrovaní používatelia týchto portálov. Z hl'adiska štruktúry sa dotazník skladal z krátkeho úvodu informujúceho o cieli a forme dotazníka. Jadro dotazníka tvorili dve časti. Prvá čast' sa venovala zist'ovaniu základných údajov o respondentovi. Druhá čast' bola pre našu prácu dôležitejšia. Skladala sa $\mathrm{z}$ ôsmych otázok, kde mal respondent možnost' výberu viacerých odpovedí a mohol v podobe otvorenej odpovedi vyjadrit' aj vlastný názor. Otázkami sme overovali 4 následné hypotézy:

- Očakávame záujem o vytvorenie nového propagačného materiálu cestovného ruchu, ktorý by verejnosti poskytoval informácie o aktívnom $C R$ v regióne dostupnými informačnými zdrojmi,

- Domnievame sa, že je dostatočná informovanost' respondentov o možnostiach turistických aktivit v regióne,

- Predpokladáme, že tradičné turistické aktivity, ako je turistika a zjazdové lyžovanie, budú najväčším lákadlom pre turistov,

- Predpokladáme, že vzhl'adom na prírodný potenciál bude Oravský región $C R$ z hl'adiska turistických aktivit prit'ažlivý.

3. V tretej fáze výskumu sme pristúpili $\mathrm{k}$ tvorbe samotného materiálu pre rozvoj $\mathrm{CR}$ vyplývajúceho z výsledkov dotazníkového prieskumu. $\mathrm{Na}$ tvorbu nami predstavovaného materiálu sme využili možnosti softvéru Microsoft Publisher 2010. Pomocou tohto programu sme vytvorili základné grafické rozhranie produktu. Následne sme produkt umiestnili na portál www.issuu.com, ktorý slúži na prezentáciu publikácií a ponúka zaujímavé možnosti prezentácie produktov $\mathrm{v}$ elektronickej forme. Textové a obrázkové materiály sme čerpali z internetových zdrojov. 


\section{Výsledky}

\section{Lokalizačné a realizačné predpoklady Oravského regiónu CR}

Z administratívnosprávneho hladiska patrí územie regiónu do Žilinského samosprávneho kraja. Územie je tvorené okresmi Námestovo, Dolný Kubín a Tvrdošín (mapa 1). Z hl'adiska Regionalizácie cestovného ruchu Slovenskej republiky susedí Oravský región CR na juhu s Liptovským, na juhozápade s Turčianskym, na západe so Severopovažským regiónom cestovného ruchu.

Oravský región cestovného ruchu je najsevernejší z celého Slovenska (mapa 1). Na jeho území leží najsevernejší bod republiky nachádzajúci sa v katastri obce Oravská Polhora. Má pomerne zretel'né prírodné ohraničenie, väčšina hraníc vedie po hrebeňoch Vonkajších Západných Karpát. Otvorená je iba severná čast', kde Oravská kotlina pokračuje smerom do Pol’ska, na tzv. pol'skú Oravu. Do značnej miery má hranica regiónu aj hydrogeografickú podobu, je takmer identický s povodím rieky Oravy. Ústie toku do Váhu pri Kralovanoch je najjužnejším bodom regiónu a zároveň aj prirodzenou vstupnou bránou na Oravu zo zvyšnej časti Slovenska.

Z prírodného hl'adiska vykazuje Oravský región cestovného ruchu dost' výraznú dualitu, členenie na dve geologicky (Biely, 2002), a geomorfologicky (Lukniš, Mazúr, 1978) odlišné časti. Rozhraničenie medzi nimi vytvára oravský úsek bradlového pásma sledujúci stredný úsek doliny rieky Oravy. Z pohladu Karpát sa na vonkajšej strane rozprestiera flyšová čast' regiónu, na vnútornej dominujú geologické resp. geomorfologické jednotky označované ako jadrové resp. kryštalicko-druhohorné s malým podielom jednotiek vnútrokarpatského flyšu. Najvyšším pohorím vonkajšej flyšovej časti regiónu sú Oravské Beskydy s dvomi dominantnými masívmi Babia hora (1725 m n. m.) a Pilsko (1557 m n. m,) vystupujúcimi nad hornú hranicu lesa s vel'hornatinovým typom reliéfu. Oravské Beskydy na juhu susedia výrazne nižším vrchovinovým reliéfom s pásmovitým usporiadaním horských chrbtov. Hlavné vodné toky sledujú výrazné a široké zníženiny s plochým dnom, ktoré je kvôli slabému odtoku zamokrené, čo v daných klimatických podmienkach prispieva k početnému výskytu pre Oravu typických rašelinísk. Dolinová siet' sa integruje v tektonicky mladej Oravskej kotline (dnes z vel'kej časti zatopenej VN Orava). Vnútornú čast' regiónu tvorí zoskupenie nižších hornatín a vrchovín, v rámci nich najvýraznejšou prírodnou bariérou chrbát Oravskej Magury kulminujúci vrchom Minčol (1394 m n. m.). Biela Orava spolu so stredným tokom Oravy masívne flyšové pohorie zo severu obtáča. Flyšovú monotónnost' Oravskej vrchoviny narúša pásmo vápencových bradiel. Na jednom z nich stojí Oravský hrad. Jadrová resp. kryštalicko-druhohorná čast' regiónu sa rozprestiera na juhu. Morfologicky výraznú hranicu voči povodiu Váhu tvoria masívne pohoria Malá Fatra na juhozápade (Vel'ký Rozsutec 1610 m n. m.) a Západné Tatry na juhovýchode s najvyšším vrchom celej Oravy Baníkovom 
(2 $178 \mathrm{~m} \mathrm{n}$. m.). Hydrogeografická bariéra medzi týmito pohoriami tvorená Chočskými vrchmi (Vel'ký Choč $1611 \mathrm{~m}$ n. m), je úzka a oslabená liptovskými prítokmi Váhu. Rozvodie je zatlačené na stranu Oravy. Oravská čast' Západných Tatier sa nazýva Roháče, má podobne členitý fosílny l'adovcový reliéf ako Vysoké Tatry. Oravský región cestovného ruchu leží v chladnej klimatickej oblasti, kde priemerné júlové teploty nedosahujú viac ako $16{ }^{\circ} \mathrm{C}$ (Lapin a kol., 2002).Takmer celé územie regiónu odvodňuje rieka Orava, ktorá je pravostranným prítokom rieky Váh, do ktorého sa vlieva pri obci Kral'ovany. Ostatnú čast', na JZ regiónu, odvodňuje rieka Váh. Na rieke Orava, v sútoku Bielej a Čiernej Oravy, bola v minulosti vybudovaná Vodná nádrž Orava, ktorá sa radí medzi najväčšie vodné diela v rámci Slovenska (Dubcová a kol., 2008). V regióne nájdeme aj niekol’ko d’alších rybníkov a jazier, pričom významné z hl'adiska turizmu sú najmä plesá v Západných Tatrách. Región je chudobný na podzemné vody. Významné vrty minerálnych termálnych vôd sú lokalizované v blízkosti turistického centra Oravice, kde je vybudovaný aquapark (Kováčik, 2011).

Mapa 1: Poloha Oravského regiónu cestovného ruchu v rámci SR Map 1: Location of Orava region of tourism within the Slovak Republic

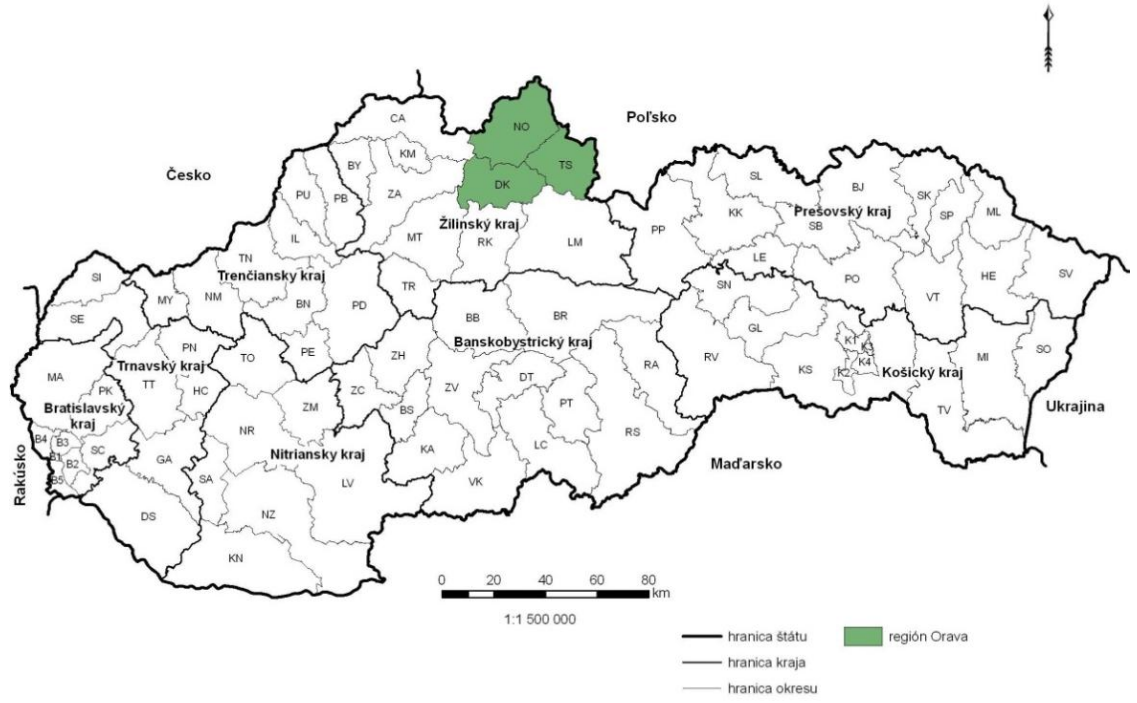

Zdroj: Kováčik, 2011

\section{Organizácie a zariadenia rozvoja $\mathrm{CR}$}

Na sledovanom území pôsobí krajská organizácia CR „Žilinský turistický kraj“, ako aj oblastná organizácia CR „Klaster Orava“. 
Hlavným účelom krajskej organizácie je podpora cestovného ruchu na území svojich členov. Krajská organizácia aktívne vytvára podmienky a realizuje aktivity, chráni záujmy svojich členov zamerané na rozvoj cestovného ruchu (www.mindop.sk).

Oblastná organizácia cestovného ruchu, je nezisková organizácia, ktorá združuje podnikatel'ské subjekty a samosprávy s ciel'om podporovat' cestovný ruch, koordinovat' marketingové aktivity svojich členov, spoločne propagovat' región doma i vahraničí, vytvárat' produkty cestovného ruchu, organizovat' kultúrne a športové podujatia.

Medzi zariadenia cestovného ruchu zamerané na poskytovanie informácií, predaj spomienkových predmetov a iného doplnkového tovaru návštevníkom patria turistické informačné kancelárie (TIK) a cestovné kancelárie. Ide o zariadenia, ktoré sa podiel'ajú na propagácii a rozvoji cestovného ruchu v ciel'ovom mieste (stredisku alebo regióne). Zriad’ujú sa $\mathrm{v}$ mestách a strediskách cestovného ruchu (www.visitorava.sk).

$\mathrm{V}$ regióne pôsobia nasledovné TIK:

- Turistické informačné centrum Trstená podáva kvalitnejší prehlad možností aktivít v regióne (Oravatic, 2018),

- Turistická informačná kancelária Zuberec ponúka predaj máp, suvenírov, sprievodcov a podáva informácie o možnostiach turistiky (Zuberec, 2018),

- Turistická informačná kancelária Dolný Kubín ponúka propagačné materiály, turistické mapy, atlasy, cykloturistické mapy a i (Dolnykubin, 2018).

V rámci zabezpečovania spolupráce prihraničných území sa rôznymi aktivitami, medzi ktoré patrí aj spolupráca v oblasti CR, zaoberajú nasledovné organizácie:

Euroregión Beskydy (Slovensko - Česko - Pol'ské partnerstvo): do jeho územia patria okresy Dolný Kubín a Námestovo, ktoré sú súčast’ou Oravského regiónu cestovného ruchu. Euroregión existuje od roku 2001 (Euroregión Beskydy, 2018). Zistili sme, že tento euroregión vytvoril nasledujúce produkty cestovného ruchu využívajúce jeho prírodný potenciál:

- Cykloturistický portál CISE, na ktorom nájdeme možnosti cykloturistiky, avšak väčšina zobrazených cyklotrás je v Českej republike.

- Internetová stránka euroregiónu (www.regionbeskydy.sk) ponúka niektoré informácie o možnostiach turistiky $\mathrm{v}$ regióne.

- Vitajte v euroregióne Beskydy; Vitajte v euroregióne Beskydy 7 a Vitajte v euroregióne Beskydy 8 sú krátke publikácie, ktoré sa z časti venujú turistickým možnostiam v Oravskom regióne cestovného ruchu. 
Euroregión Tatry (Slovensko - Pol'ské partnerstvo): do jeho územia spadá celý Oravský región cestovného ruchu (Euroregión Tatry, 2018). Euroregión ponúka nasledovné produkty cestovného ruchu, ktoré sa venujú aj Oravskému regiónu CR:

- Typy na víkend sú pravidelne vydávané plagáty, kde sa uvádzajú možnosti výletov a kultúrnych podujatí v euroregióne.

- Pamiatky siedmich kultúr v slovenských mestách Euroregiónu „,Tatry“ je knižná publikácia, ktorá sa venuje hlavne kultúrnym pamiatkam a kultúre v euroregióne, ale nájdeme tu informácie aj o prírode.

- Mapa prameňov je dielo, ktoré zobrazuje najvýznamnejšie pramene $\mathrm{v}$ euroregióne.

V záujmovom území pôsobia aj d'alšie organizácie, ktoré sa podiel'ajú na propagácii územia:

- Agentúra pre regionálny rozvoj SEVER - vytvorila kartovú hru Poznáš región Oravu?, ktorá sa skladá z množstva kartičiek, kde sú prezentované rôzne zaujímavosti regiónu (Arr.szm, 2018).

- Oblastná organizácia cestovného ruchu Klaster Orava vydala publikáciou Orava turistický sprievodca, táto publikácia prezentuje niekol'ko vybraných zaujímavostí v regióne (Issuu, 2018). Uvedená organizácia vytvorila aj Turisticko informačný portál regiónu Orava.

- Informačné centrum Námestovo vydalo publikáciu Orava turistický sprievodca, ktoré prezentuje niektoré zaujímavosti v regióne prírodného aj kultúrneho charakteru (Orava, 2018).

O Oravskom regióne CR boli vydané rôzne propagačné materiály:

- Orava turistický sprievodca prezentuje región Oravu z hl'adiska jeho kultúrnych a prírodných daností (Hencovský, 1990).

- Turistický sprievodca Orava je historicko-vlastivedno-turistický sprievodca po Orave, obsahuje základnú charakteristiku prírodných pomerov oblasti, jej histórie, obyvatel'stva a sídel. Ako aj výber peších turistických a cyklistických trás s praktickými informáciami (Kollár, 2001).

- Knižná publikácia Po Slovenku - Oravské Beskydy sa venuje turistickým možnostiam v Oravských Beskydách (Kollár, Lacika, 2018).

- Potulky krajom - internetový sprievodca (Oravainfo, 2018).

- vytvorený Klastrom Orava (Orava, 2018).

- Orava pass - karta zliav pre vlastníkov karty Orava pass, ktorá je hlavným produktom Klastru Orava (Oravapass, 2018).

\section{Dotazníkový prieskum}

Pred tvorbou dotazníka sme si stanovili štyri hypotézy, ktoré sme si overili. Na základe dotazníkového prieskumu môžeme konštatovat', že až 96 \% zapojených 
respondentov navštívilo predmetný región aspoň jedenkrát $\mathrm{v}$ živote a z nich až 80 $\%$ z dôvodu turistiky. V ovel'a nižšej miere respondenti využívajú ostatné tradičné aktivity, ktoré územie ponúka, ako zjazdové lyžovanie, zimnú turistiku, vodné športy, relax a zábavu v aquaparkoch a kúpaliskách. Netradičné aktivity, ako adrenalínové športy, splavy a geocaching respondenti využívajú len minimálne. Z hl'adiska dostupnosti informácií o turistických aktivitách v regióne sme zistili, že tri štvrtiny respondentov vyhl'adáva informácie pomocou internetu, alebo cez rodinu. Ostatné informačné zdroje využívajú len vo vel'mi malej miere. Zároveň však až $85 \%$ respondentov považuje informovanost' o turistických aktivitách v regióne za nedostatočnú. Uvedené výsledky nás viedli $\mathrm{k}$ názoru, že kvalitných informácií o možnostiach aktivít je v regióne málo a vidíme tu vel'ký priestor na realizáciu nových materiálov, ktoré by informovanost' respondentov zvýšili. Toto tvrdenie potvrdzuje $76 \%$ respondentov, ktorí uvádzajú, že majú málo informácií najmä o netradičnejších aktivitách ako sú adrenalínové športy, cyklistika, vodné športy, splavy a geocaching. Respondenti by prijali zvýšenie informovanosti najmä o adrenalínových športoch, cyklistike a pešej turistike. Ďalej konštatujeme, že až $86 \%$ respondentov by privítalo vznik materiálu, ktorý by obsahoval kvalitné informácie o možnostiach turistických aktivít v regióne v elektronickej podobe.

\section{Návrh propagačného materiálu}

Dôvody vytvorenia navrhovaného materiálu boli podložené z dotazníkového výskumu, kde až $76 \%$ respondentov uviedlo, že má nízku informovanost' o možnosti adrenalínových športov v regióne. Pričom 52\% respondentov uviedlo, že by prijalo viac informácií o práve týchto-športoch. Do úvahy sme brali aj informáciu, že až $76 \%$ respondentov čerpá informácie o možnostiach cestovného ruchu z internetu. Ďalším dôvodom vzniku spomínaného propagačného materiálu, bolo tiež zistenie, že v rámci regiónu sme neobjavili podobný produkt, ktorý by prezentoval možnosti propagácie adrenalínových športov v elektronickej forme. Na základe dopytu na trhu bol vyhotovený materiál elektronickej publikácie, ktorý je sprístupnený na www.issuu.com a prezentuje možnosti adrenalínových športov v Oravskom regióne cestovného ruchu. V elektronickej forme sme navrhli sprievodcu existujúcich adrenalínových športov uvedeného regiónu. Zistili sme, že v regióne je realizovaných osem adrenalínových športov. Ide o paintball, paraglaiding, rafting, skalolezectvo, jazdy na motorových vozidlách - na štvorkolkách, tankoch, skialpinizmus. Každý šport je v elektronickom sprievodcovi všeobecne charakterizovaný, obsahuje informácie o subjektoch, ktoré zabezpečujú jeho realizáciu ako aj výstižné fotografie (obr. 1). 
Obr. 1: Ukážka navrhovaného produktu

Figure 1:Demo of the proposed product

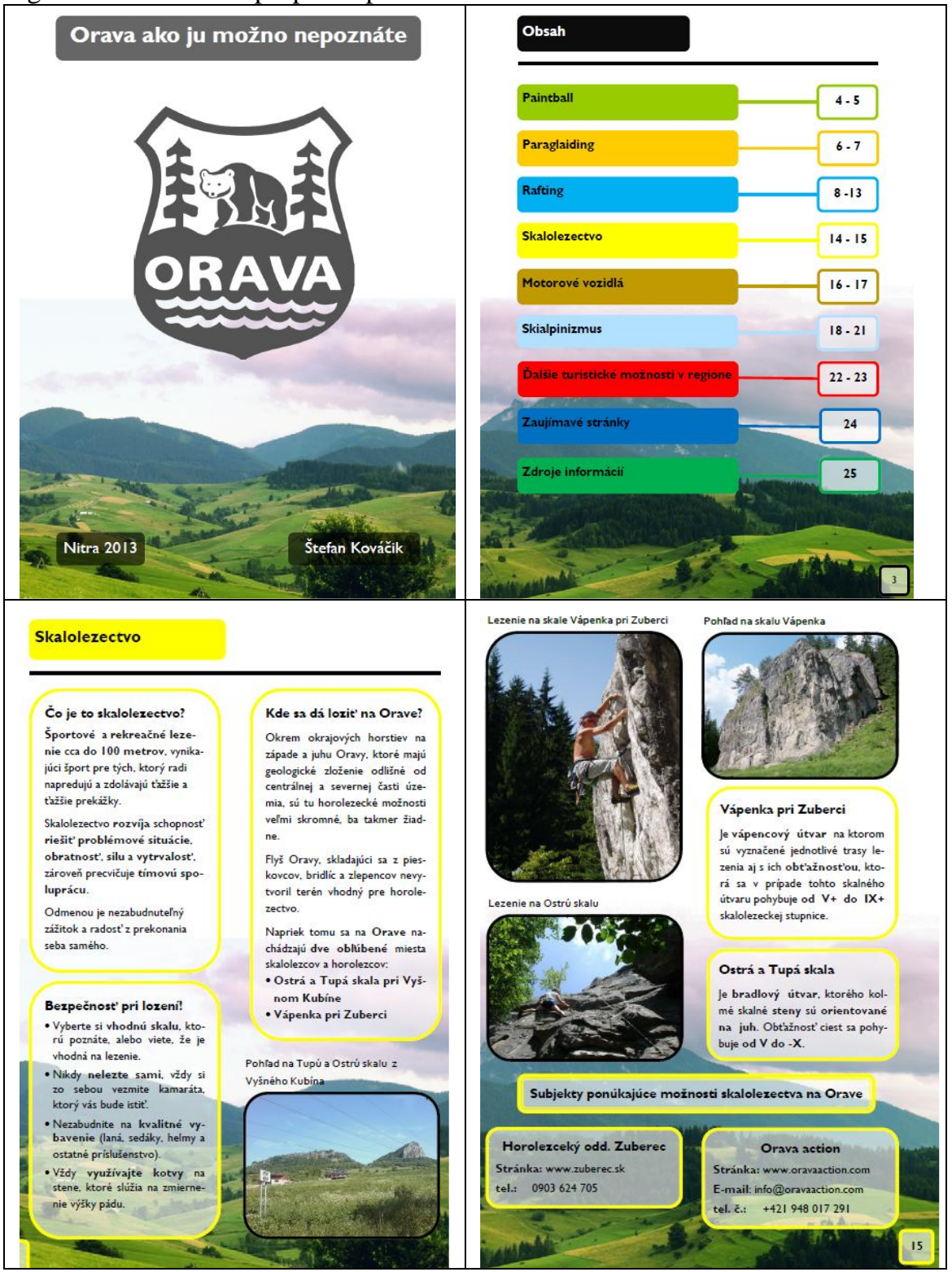




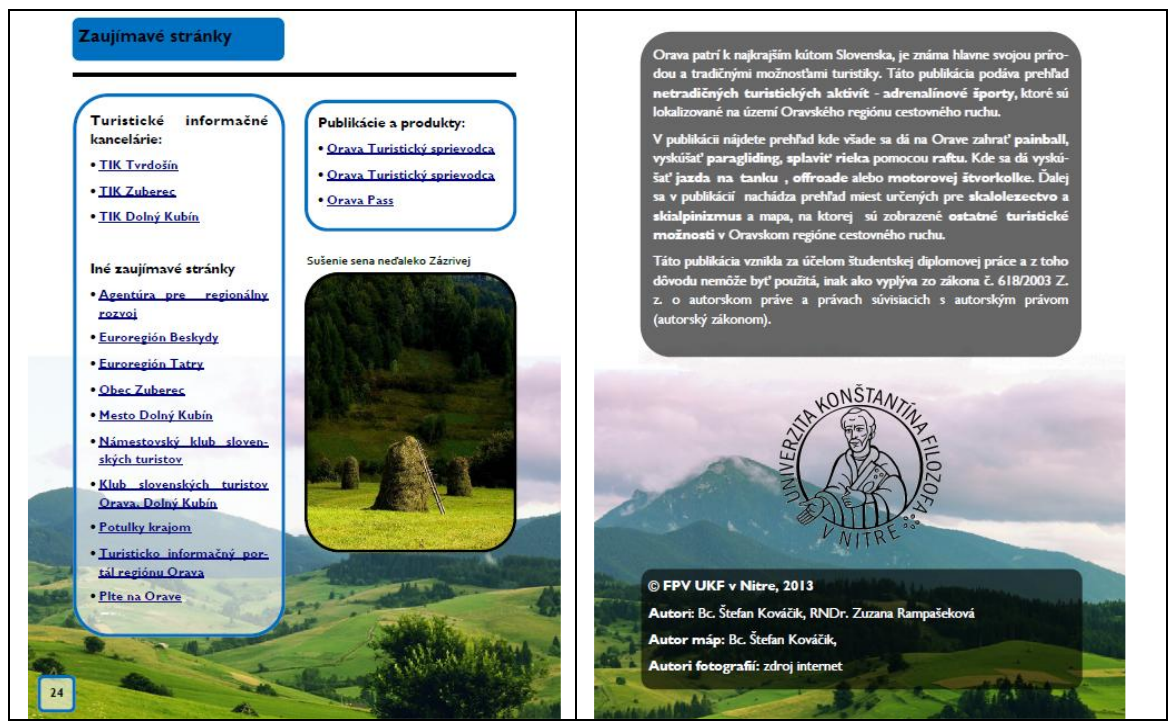

\section{Záver}

Na základe analýzy prírodného prostredia a prieskumu trhu dotazníkovou formou sme vytvorili v elektronickej podobe propagačný materiál, ktorý by mohol uspokojit' potreby po neopakovatel'ných zážitkoch viac ako $50 \%$ návštevníkov Oravského regiónu cestovného ruchu.

Prieskum trhu sme zamerali na organizácie a zariadenia, ktoré sa podiel'ajú na tvorbe materiálov propagujúcich región, ako aj na samotné existujúce materiály zamerané na prírodný potenciál celého priestoru. Po prieskume je však zrejmé, že jednotlivé organizácie a zariadenia vytvárajú v rámci marketingu materiály cestovného ruchu, ale medzi sebou málo spolupracujú. Zistili sme tiež, že len málo materiálov je dostupných pre verejnost' $\mathrm{v}$ rámci internetu. Taktiež kvalita mnohých informačných zdrojov je vel'mi nízka, podobne je na tom aj kvalita a aktualita informácií.

Pre stimuláciu dopytu sme sa rozhodli vytvorit' vol'ne dostupný nehmotný materiál CR v elektronickej forme, propagujúci existujúce adrenalínové športy v regióne s názvom „Orava ako ju možno nepoznáte“ (https://issuu.com). Na jeho propagáciu sme vybrali viac účinnú ako nákladnú formu prostredníctvom elektronických technológií, ktoré pomáhajú zvyšovat' dopyt po spoznávaní Oravského regiónu CR a priniest' jeho dlhodobú prosperitu. 


\section{Literatúra}

ARR.SZM. 2018. http://www.arr.szm.com/karty.htm [cit. 2018-09-02]

BIELY, A. 2002. Geologická stavba. Mierka 1 : 500 000. In Atlas krajiny Slovenskej republiky. 1. vyd. Bratislava: SAV Bratislava, Banská Bystrica: SAŽP, 2002. 344 s. ISBN 80-88833-27-2.

DOLNYKUBIN. 2018. http://www.dolnykubin.sk/ [cit. 2018-09-02]

DUBCOVÁ, A. a kol. 2008. Geografia Slovenska. Nitra: UKF v Nitre, 2008. 351 s. ISBN 978-80-8094-422-3.

EUROREGIÓN BESKYDY. 2018. http://www.regionbeskydy.sk/143/uvod/ [cit. 2018-09-02]

EUROREGIÓN TATRY, 2018. http://www.euroregion-tatry.sk/w3/index.php [cit. 2018-09-02]

GÚČIK, M. 2000. Základy cestovného ruchu. Banská Bystrica: Ekonomická fakulta UMB, 2000. 152 s. ISBN 80-8055-355-6.

GUČÍK, M. a kol. 2006. Cestovný ruch - hotelierstvo - pohostinství. Výkladový slovník. 1. vyd. Bratislava: SPN, 2006. 216 s. ISBN 80-10-00360-3.

ISSUU. 2018. http://issuu.com/glonco/docs/sprievodca-orava [cit. 2018-09-02]

KOLLÁR, D. 1990. Turistický sprievodca Orava. Bratislava: Dajama, 1990. $190 \mathrm{~s}$.

KOLLÁR, D. - LACIKA, J. 2010. Po Slovenku - Oravské Beskydy. Bratislava: Dajama, 2010. $160 \mathrm{~s}$.

KOVÁČIK, Š. 2011. Prírodné predpoklady rozvoja cestovného ruchu Oravského regiónu. Bakalárska práca. Nitra: FPV UKF, 2011. $55 \mathrm{~s}$.

KUHN, I. - TOMÁŠOVÁ, P. Úvod do destinačného manažmentu. Príručka pre samosprávy, podnikatel'ské a iné subjekty k zakladaniu a činnosti organizácií cestovného ruchu podl'a zákona č. 91/2010 Z.z. o podpore cestovného ruchu v znení neskorších predpisov.

LAPIN, M. a kol. 2002. Klimatické oblasti. Mierka 1 : 1000 000. In Atlas krajiny Slovenskej republiky. 1. vyd. Bratislava: SAV Bratislava, Banská Bystrica: SAŽP, 2002. 344 s. ISBN 80-88833-27-2.

MAZÚR, E. - LUKNIŠ, M. 1978. Regionálne geomorfologické členenie Slovenskej socialistickej republiky. In Geografický časopis. roč. 30, č. 2, s. 101-124.

MDVaRRSR. Terminológia vybraných pojmov $v$ cestovnom ruchu. http://www.telecom.gov.sk/index/open_file.php?file=cestovnyruch/Cestovnyru $\mathrm{ch} /$ terminologiaCR.pdf [cit. 2018-09-02]

ORAVA. 2018. http://www.orava.sk/data/files/orava_turisticky_sprievodca.pdf [cit. 2018-09-02]

ORAVAINFO. 2018. http://www.orava.info [cit. 2018-09-02]

ORAVAPASS. 2018. http://www.oravapass.sk/index.php?lang=sk\&menuid=103 [cit. 2018-09-02]

ORAVATIC, 2018. http://www.oravatic.sk [cit. 2018-09-02] 
ORAVA JAKO JU MOŽNO NEPOZNÁTE. 2018. https://issuu.com/tyalnor/docs/ orava_ako_ju_mozno_nepoznate [cit. 2018-09-02]

SAŽP. Definícia mikroregionálnych združení. http://www.sazp.sk/ mikroregiony/ [cit. 2018-09-02]

ŠOLCOVÁ, L. - KASAGRANDA, A. - KROGMANN, A. 2012. Návrhy tematických trás $\mathrm{v}$ obci Prečín a jeho bezprostrednom okolí. In GEO Information 8. Nitra: UKF, 2012. ISSN 1336-7234, s. 63-73.

ÚZEMNÝ PLÁN $\quad$ OBCE $\quad$ KRALOVANY. 2018. https://www.obeckralovany.sk/app/uploads/2017/02/Text_na\%CC\%81vrhU\%CC\%81PN-O-Kral\%CC\%8Covany.pdf [cit. 2018-09-02]

ZÁKON 91/2010 Z. z. o podpore regionálneho rozvoja.

ZUBEREC. 2018. http://zuberec.sk [cit. 2018-09-02]

\section{PROPOSAL TO INCREASE ATTRACTIVENESS OF THE ORAVA TOURISM REGION BY ELECTRONIC TECHNOLOGIES}

\section{Summary}

Based on the analysis of the natural environment and the market research in terms of the available tourism promotional material and the knowledge of customer needs, we elaborated a proposal of the demand absence of Orava tourist region by the electronic questionnaire method. It is a product that we recommend for the accommodation facility in terms of long-term prosperity. Many accommodation facilities focus only on standard services such as accommodation, catering, wellness services, but they forget to create a program for their guests and to explore the beauty of Orava's natural potential.

During the research we found out that there are no promotional material creation services in our territory that would increase the image of the region and at the same time allow visitors to relax in this destination. We have therefore decided to create a product, methodology and presentation method that will ensure the promotion of the region to the greatest extent possible.

For the uniqueness of tourist product we propose its implementation in three phases: in the first analytical phase of research, we recommend focusing on market research. In our case, we have found that within the Orava region of tourism there are several entities whose aim is to develop tourism and create promotional materials. There were two regions of European importance - the Euroregion Beskydy, the Euroregion Tatry, 4 micro-regions, 3 TIK (tourist information agency) and 9 other information sources. This phase of the process thoroughly recommend. Although it is very time consuming, but avoids duplication of promotional material. After a thorough analysis, it was clear that individual institutions create tourism products in marketing, but do not cooperate with each other. We also found that few promotional materials are available to the public on 
the Internet. Also, the quality of many information sources is very low, similar is the quality of news and information.

In the second phase, it is advisable to focus on product planning, which we propose to verify in a questionnaire form. Through respondents, we found that the market is missing a product that would inform about non-traditional activities such as extreme sports, cycling, water sports, rafting and geocaching... .

In the third phase of research, we proceeded to create the product itself. We decided for the product in the form of an electronic publication that is available at www.issuu.com and presents the possibilities of adrenaline sports in the Orava region of tourism. In electronic form we have designed a guide to existing adrenalin sports in the region. These are paintball, paragliding, rafting, rock climbing, motor vehicle rides - focusing on quads and military equipment and alpine skiing. Each sport is generally characterized by electronic guide contains information on entities that ensure its implementation and useful photographs.

To stimulate demand, we have decided to create a freely available intangible tourist product in electronic form. We have created a brand of new original product focused on the presentation of the existing extreme sports in the region called "Orava ako ju možno nepoznáte" (www.issuu.com). For its promotion, we have chosen more effective than expensive form via electronic technologies that help stimulate demand and bring long-term prosperity of the area.

RNDr. Zuzana Rampašeková, PhD.

Doc. RNDr. Ján Lacika, CSc.

Mgr. Štefan Kováčik

Katedra geografie a regionálneho rozvoja FPV UKF v Nitre

Trieda A. Hlinku 1, 94974 Nitra

E-mail: zrampasekova@ukf.sk, jlacika@ukf.sk 